\title{
ANALISIS PENERAPAN PRINSIP KEADILAN, AL-IHSAN, AL- MAS'ULIYAH, AL-KIFAYAH, DAN KEJUJURAN DALAM BISNIS RITEL (Studi Kasus MBS Madiun Teguhan Jiwan Madiun)
}

\author{
Muhamad Abdulloh \\ Institut Agama Islam Negeri Ponorogo \\ e-mail : achmadabdulloh77@gmail.com
}

\begin{abstract}
In this era of globalization, many retail businesses are starting to develop, especially the types of minimarkets, the number of minimarkets making the competition heats up. This makes entrepreneurs rack their brains to create good strategies to attract consumer interest, including applying sharia principles in their operations. This study seeks to determine how the application of sharia principles to the retail business in the city of Madiun. This research uses case studies by making shop owners the primary data source of research, while secondary data is from supporting information related to research conducted either from observations or literature sources or relevant previous research. The results showed that the strategy of applying sharia principles in several aspects, namely, aspects of products, services, marketing, and distribution of profits to those in need is in accordance with Islamic sharia. The application of sharia principles also provides a special attraction for consumers, thereby increasing mini-market sales.
\end{abstract}

Keywords: Sharia Principles, and retail business

Abstrak: Di era globalisasi seperti sekarang ini mulai banyak berkembang bisnis ritel khususnya jenis minimarket, banyaknya minimarket membuat persaingan semakin memanas. Hal tersebut membuat para pengusaha memutar otak untuk membuat strategi yang baik guna menarik minat konsumen diantaranya adalah dengan menerapkan prinsip-prinsip syariah dalam operasionalnya. Penelitian ini berusaha mengetahui bagaimana prinsip-prinsip syariah yang diterapkan pada bisnis ritel yang ada di kota Madiun. Penelitian menggunakan studi kasus dengan menjadikan pemilik toko sebagai sumber data primer penelitian, sedangkan data sekunder dari informasi-informasi pendukung terkait penelitian yang dilakukan baik dari pengamatan maupun sumbersumber pustaka ataupun penelitian terdahulu yang relevan. Hasil penelitian menunjukkan bahwa dengan strategi menerapkan prinsip-prinsip syariah dibeberapa aspek yaitu, aspek produk, pelayanan, pemasaran, dan penyaluran keuntungan kepada yang membutuhkan sudah sesuai dengan syariah Islam. Penerapan prinsip-prinsip syariah juga memberikan kesan baik dimata para konsumen sehingga meningkatkan penjualan minimarket.

Kata Kunci : Prinsip Syariah, Bisnis retail

\section{PENDAHULUAN}

Semakin berkembangnya zaman seperti sekarang ini, perkembangan market atau pasar juga mengalami perkembangan yang signifikan khususnya usaha pada bidang retail. Hal tersebut dapat kita ketahui dengan semakin banyaknya toko-toko yang bermunculan. Semakin banyaknya toko mengakibatkan pasar tradisional menjadi 
terancam dan mulai tergeser keberadaaanya. Adanya persaingan antara pasar tradisional dan modern banyak terjadi di seluruh daerah khususnya kota besar di Indonesia. Persaingan tersebut terjadi karena semakin sedikitnya penawaran ketimbang permintaan. Oleh karena itu kita sebagai pengusaha atau enterpreneur muslim dituntut untuk berpikir kedepan sehingga tidak semakin tertinggal dari para pesaing. Munculnya pesaing dikarenakan banyaknya kesempatan untuk memasuki pasar dan dengan menciptakan sebuah produk atau jasa baru yang lebih unggul dalam hal spesifikasi dari produk atau jasa sebelumnya(Andriani, 2019).

Sekarang ini konsumen tidak hanya berfokus kepada harga yang murah melainkan juga faktor yang lain seperti pelayanan yang baik saat bertransaksi, fasilitas yang didapatkan, serta kualitas produk yang bagus dan terjamin. Hal tersebut memberikan kesan tersendiri bagi para konsumen. karena itu dalam memulai sebuah bisnsi retail dengan model pasar modern seperti minimarket, enterpreneurs harus mempelajari berbagai aspek yang berkaitan dengan usaha yang digeluti tersebut.

Dalam Islam sendiri, hubungan antara sesama manusia atau hablum minannas sudah diatur dalam syariah, begitu juga dalam muamalah melakukan jual beli. Seseorang yang melakukan jual beli harus memperhatikan prinsip prinsip syariah. Prinsip-prinsip syariah dapat diartikan sebagai suatu aturan atau kebijakan dalam perjanjian yang didasarkan pada suatu etika dalam bisnis Islam yang terjadi antara pebisnis dengan konsumen atau bisa juga antara bank dengan nasabah untuk melakukan kegiatan bisnis berdasarkan syariat Islam. Prinsip-prinsip syariah tersebut meliputi prinsip keadilan, prinsip al-ihsan (berbuat kebaikan), prinsip al-mas'uliyah (pertanggungjawaban), prinsip al-Kifayah, prinsip keseimbangan, dan prinsip kejujuran dan kebenaran(Andriani, 2019).

Berdasarkan prinsip-prinsip syariah diatas, maka prinsip syariah secara umum dapat disimpulkan sebagai segala bentuk sumber daya baik manusia atau alam dalam ekonomi Islam dipandang sebagai titipan atau pemberian dari Allah Swt yang diperuntukan dan dimanfaatkan sebagaimana mestinya oleh manusia sebagai khalifah di muka bumi. Sebagai entrepreneur muslim ketika memulai sebuah usaha harus memperhatikan prinsip-prinsip dalam syariat Islam, sehingga dalam menjalankan kegiatan bisnisnya tidak merugikan pihak yang lain dan agar bisa mendapat kemalsahatan bersama(Mardani, 2015, hlm. 16). 
Seiring dengan perkembangan zaman, jiwa entrepreneur seseorang juga semakin terpacu untuk memulai atau menciptakan sebuah usaha atau bisnis dengan adanya dukungan Ilmu pengetahuan dan teknologi yang semakin canggih sehingga memudahkan untuk memulai bisnis. Maka tidak heran jika banyak pebisnis yang memulai membuka usahanya pada bidang retail modern yaitu mini market yang saat ini berkembang pesat di Indonesia. Minimarket sendiri dapat diartikan sebagai sebuah bangungan atau usaha yang menyediakan dan menjual kebutuhan pokok, barang konsumsi, terutama produk rumah tangga dan makanan secara satuan. Minimarket syariah merupakan usaha atau bisnis yang beroperasi di bidang retail serta menerapkan atau menggunakan prinsip-prinsip syariah dalam kegiatan bisnisnya.

Dari berbagai minimarket yang ada di kota Madiun, diantaranya terdapat salah satu minimarket syariah yaitu MBS Madiun. Minimarket MBS Madiun merupakan suatu usaha pada bidang retail yang menerapakan prinsip-prinsip Syariah. MBS Madiun berdiri tanggal 28 April 2019 yang beralamat di J1 Dandang Gendis, Teguhan, Jiwan, Madiun. MBS Madiun mengusung prinsip syariah dalam distribusi dan jual beli yang mana hanya mendistribusikan produk yang sesuai syariat Islam dan memperjualbelikan barang-barang yang terbukti kehalalanya.

Dengan melihat sejauh mana minimarket syariah yang ada di Indonesia dalam menerapkan prinsip sesuai dengan syariah yaitu prinsip keadilan, prinsip al-ihsan (berbuat kebaikan), prinsip al-mas'uliyah (pertanggungjawaban), prinsip al-kifayah, prinsip keseimbangan, dan prinsip kejujuran dan kebenaran. Sehingga minimarket tersebut dapat berkembang di tengah era globalisasi seperti sekarang ini, oleh karena itu, penelitian ini akan mengkaji lebih mendalam mengenai penerapan atau implementasi prinsip-prinsip syariah yang sudah diterapkan oleh minimarket MBS Madiun. Selain itu penelitian minimarket pada MBS Madiun juga untuk melihat apakah praktik yang berada di minimarket tersebut telah benar-benar syar'i atau belum.

Masalah mengenai penerapan prinsip-prinsip syariah sebenarnya telah dikaji memang banyak diteliti baik dalam buku, skripsi, makalah, artikel, dan karya ilmiah lainnya. Namun peneliti berusaha mencari celah diantaranya skripsi oleh Rika Andriani dengan judul “Analisis Penerapan Prinsip-Prinsip Syariah Pada Bisnis Ritel Syariah Di Minimarket Sakinah 212 Mart Wonorejo Tandes Surabaya”. Yang meneliti tentang proses pelaksanaan penerapan prinsip-prinsip syariah pada bisnis ritel syariah. Dari skripsi ini dapat disimpulkan bahwa, penerapan prinsip-prinsip syariah pada bisnis di 
bidang ritel syariah "Minimarket Sakinah 212 Mart" dalam menjalankan kegiatan bisnisnya dapat dilihat pada beberapa aspek yaitu, pada aspek produk yang tersedia, minimarket menerapkan prinsip al-mas'uliyah (bertanggung jawab) dengan menerapkan kebijakan untuk memperjualbelikan produk yang terjamin halal. Pada aspek pelayanan, minimarket menerapkan prinsip iḥsan pada kebijakannya, yaitu dengan memberikan pelayanan yang terbaik (service exellence) kepada para konsumen yang datang ke minimarket dan penerapan prinsip al-mas'uliyah (bertanggung jawab) dalam kebijakannya yaitu mempertanggungjawabkan konsekuensi yang terjadi jika konsumen merasa kurang puas atau komplain(Andriani, 2019).

Pada aspek pemasaran, prinsip yang diterapkan oleh minimarket ini adalah prinsip kejujuran (al-șidq) dan kebenaran yang dalam praktiknya melakukan promosi dengan jujur dan tidak melakukan kebijakan sendiri dalam menentukan harga atau manipulasi harga. Pada aspek sistem kerjasama dan bagi hasil dengan mitra, minimarket menerapkan prinsip al-kifayah (tolong-menolong), karena dalam penerapannya antar minimarket dan mitra saling membutuhkan bantuan dana dengan cara bersyirkah. Dan juga Skripsi oleh Lamtiur Mayogi Rohana Pasaribu dengan judul “Analisis Prinsip Dan Penerapan Etika Bisnis Islam Terhadap Kemajuan Bisnis (Studi Pada Swalayan Surya Jalan Ryacudu Jalur Dua Korpri)". Yang membahas tentang dampak penerapan prinsip dan etika bisnis Islam yang berpengaruh terhadap kemajuan bisnis swalayan surya jalan ryacudu jalur dua korpri. Kesimpulan skripsi ini yaitu, prinsip etika bisnis Islam yang diterapkan pihak swalayan surya jalan jalur dua korpri telah sepenuhnya menerpakan etika bisnsi Islam. Hal tersebut tercermin dari beberapa aspek yaitu, aspek manajemen, aspek pemasaran, aspek sumber daya manusia, serta aspek sosial(Pasaribu, 2019).

Berasal dari beberapa penelitian tersebut, penelitian ini dilakukan untuk mengkaji lebih mendalam mengenai penerapan prinsip-prinsip syariah yang pada bisnis ritel khusunya MBS Madiun serta mengetahui dampak penerapan prinsip-prinsip syariah tersebut terhadap konsumen MBS Madiun. Sehingga penulis memilih judul “Analisis Penerapan Prinsip Keadilan, Al-Ihsan, Al-Mas'uliyah, Al-Kifayah, Dan Kejujuran Dalam Bisnis Ritel” (Studi Kasis MBS Madiun Teguhan Jiwan Madiun) 


\section{TINJAUAN PUSTAKA}

\section{Prinsip-prinsip Syariah}

Islam sebagai agama yang menyeluruh mengatur segala hubungan baik dengan sesama manusia (hablu al-minannas), dengan Allah SWT (hablu al-minaAllah) dan manusia dengan lingkungan alam atau lingkungan disekitarnya. Termasuk muamalah sesama manusia seperti aktivitas ekonomi yang juga diatur dalam al-Qur'an dan Sunnah sebagai sumber ajaran agama Islam. Dalam melakasanakan aktivitas ekonomi yang berbasis syariah. Pebisnis muslim atau entrepreneur muslim harus menerapkan prinispprinsip syariah yang sesuai dengan aturan-aturan Islam(Andriani, 2019).

Prinsip-prinsip syariah adalah suatu kebijakan atau aturan dalam perjanjiaan ekonomi atau kegiatan ekonomi yang didasarkan pada etika bisnis Islam yang terjadi antara produsen atau suplier dengan konsumen untuk melakukan kegiatan bisnis berdasarkan syariat.Prinsip-prinsip syariah dalam ekonomi Islam (Mursal, 2015). Prinsip-prinsip syariah dalam ekonomi Islam adalah sebagai berikut:

a. Prinsip keadilan, keadilan mencakup semua aspek kehidupan manusia. Keadilan sendiri merupakan prinsip yang sangat penting. Keadilan dapat diartikan dengan menempatkan sesuatu hanya pada tempatnya, memberlakukan sesuatu sesuai dengan posisinya, dan memberikan sesuatu kepada yang benar-benar berhak untuk menerima. Penerapan prinsip keadilan dalam aktivitas ekonomi dapat berupa aturan atau kebijakan yang melarang adanya unsur riba, maysir, gharar dalam praktik pelaksanaan transaksi ekonomi. Rasulullah dalam melakukan jualbeli (berbisnis) selalu menjunjung tinggi keadilan dan selalu menerapkan kaidahkaidah Islam dalam aktivitas ekonomi yang beliau lakukan. Prinsip keadilan harus diimplementasikan dalam seluruh aspek kehidupan bermasyarakat agar tidak terjadi hal-hal yang dapat merusak hubungan antar manusia, seperti tindakan penghinaan, kekerasan, pengucilan dan lainnya. Keadilan dalam aktivitas ekonomi bisa berupa adil dalam menimbang artinya tidak adanya kecurangan dalam menimbang, adil dalam penentuan harga artinya harga yang ditetapkan tidak terlalu murah atau tidak terlalu mahal (sama dengan pedagang yang lain) sehingga tidak mematikan pasar, dan dalam kualitas produk yakni sesusai dengan speksifikasi yang sebenarnya.

b. Prinsip al-ihsan (berbuat kebaikan), pemberian manfaat kepada orang lain berdasarkan hak orang lain tersebut. Prinsip ini dilakukan agar pelaku bisnis tidak 
ragu-ragu dalam melakukan kegiatan ekonomi. Dengan menerapakn prinsip alihsan kita dapat memberikan yang terbaik yang mampu kita berikan. Dalam aktivitas ekonomi kita dapat memberika pelayanan yang maksimal atau service excellent kepada konsumen.

c. Prinsip al-Mas'uliyah (pertanggung jawaban, accountability), yang meliputi beberapa aspek, yakni tanggungjawab dalam masyarakat (al-mas'uliyah almujtama'), tanggungjawab antara individu dengan individu (al-mas'uliyah alafrad),. Dalam hidup bermasyarakat manusia diwajibkan untuk melaksanakan kewajibannya agar tercipta kesejaheraan dalam masyarakat. Adanya prinsip tanggungjawab dalam diri seorang pebisnis muslim akan membuatnya lebih berhati-hati dalam melakukan aktivitas ekonomi sehingga tidak melakukan tindakan yang akan berdampak buruk bagi dirinya dan orang lain.

d. Prinsip al-kifayah (sufficiency), pokok tujuan dari prinsip ini adalah untuk mengurangi kefakiran dan membantu untuk mencukupi kebutuhan anggota masyarakat. Dengan cara menyisihkan sedikit keuntungan untuk disalurkan kepada mereka yang benar-benar membutuhkan.

e. Prinsip kejujuran dan kebenaran yaitu, dalam aktivitas ekonomi seorang pebisnis muslim mengutamakan akhlakul karimah yaitu berperilaku jujur dan kebenaran. Praktiknya dalam kegiatan ekonomi adalah jujur dalam bertransakasi, tidak menjual barang yang sudah rusak atau kurang sempurna kemudian dikatakan sempurna.

\section{Bisnis Ritel}

Bisnis retail merupakan usaha yang menyediakan produk atau jasa sebagai nilai tambah untuk memenuhi kebutuhan konsumen baik secara individu (pribadi), keluarga, kelompok masyarakat atau pemakai akhir. Ritel adalah sekelompok kegiatan yang menjual atau menambahkan nilai barang dan jasa untuk konsumen(Soliha, 2008).

Bisnis ritel merupakan bisnis yang menawarkan produk untuk dipakai oleh para konsumen. Jenis produk seperti makanan biasanya memiliki tingkat kadaluarsa yang lebih singkat ketimbang produk kecantikan dan lainnya. Bisnis ritel biasanya menjual kepada konsumen yang menggunakan langsung produk yang dibeli bukan untuk dipasarkan kembali(Kotler, 2016, hlm. 431). 


\section{Bisnis ritel Syariah}

Pengertian bisnis ritel syariah sedikit berbeda dengan bisnis ritel biasanya yang mana pengertian bisnsi ritel syariah adalah suatu bisnis untuk memenuhi kebutuhan konsumen di mana kegiatannya adalah menyalurkan barang atau jasa kepada individu, keluarga, dan kelompok masyarakat, di mana harta yang digunakan, cara mendapatkan harta yang mereka miliki sesuai dengan tuntunan Nabi Muhammad SAW yang bersumber dari al-Qur'an dan as-sunnah(Manan, 2012, hlm. 35).

Dalam Islam, terdapat kebijakan yang melarang menjual barang yang belum benar-benar dimiliki, dan barang yang tidak jelas cara memperoleh maupun proses produksinya. Selain itu larangan menjual barang yang sudah rusak, menjual barang yang tidak memiliki manfaat dan lainnya.

Sehingga dalam bisnis ritel syariah pebisnis harus lebih berhati-hati mengenai proses distribusi dan transaksi dengan konsumen. Yang mana harus memperhatikan proses pembuatan barang, proses distribusi barang, kemudian juga adanya saling ridho dalam proses transaksi dengan konsumen.

\section{METODE PENELITIAN}

Metode yang digunakan dalam penelitian ini adalah penelitian kualitatif dan kepustakaan. Penelitian kepustakaan merupakan penelitian yang digunakan dalam memperoleh atau mengumpulkan informasi dan data dengan bantuan berbagai macam material yang ada di perpustakaan seperti dokumen, buku, majalah, kisah-kisah sejarah, berita dan sebagainya. Menurut ahli penelitian kepustakaan merupakan kajian teoristis, referensi serta literatur ilmiah lainnya yang berkaitan dengan budaya, nilai dan norma yang berkembangan pada situasi sosial yang diteliti (Sugiono, 2014). Sedangkan penelitian kualitatif adalah penelitian berdasarkan data yang berbentuk kata-kata dan bukan angka. Biasanya data ini digunakan untuk menjelaskan karakteristik suatu sifat. Dalam penelitian ini, data yang diperoleh berasal dari artikel-artikel pada jurnal online dan berita(Sugiono, 2014). Peneliti melakukan pencarian artikel dengan menggunakan keyword "Penerapan prinsip-prinsip syariah"dan "Bisnis ritel". Dari 4 sumber yang diperoleh, peneliti memilih 3 sumber yang dinilai relevan.

Dalam penelitian ini, narasumber yang terlibat sebanyak 1 orang, yaitu pimpinan toko. Untuk menjaga identitas dari narasumber peneliti memberi nama pengganti narasumber dengan P1 yang berusia 21 tahun dengan Pendidikan SMA Sederajat dan 
berjenis kelamin laki-laki. Wawancara dengan narasumber dilakukan secara tersturktur dengan beberapa pertanyaan yang telah disusun dan dikaitkan serta dikembangkan sehingga menjadi literatur yang ilmiah.

Untuk mendapatkan temuan melalui analisis, peneliti mengajukan beberapa pertanyaan sebagai bahan menggali dan memperoleh informasi dari narasumber. Berikut merupakan pertanyaan yang peneliti ajukan kepada narasumber.

a. Bagaimana penerapan prinsip-prinsip syariah di Toko MBS Madiun?

b. Apa alasan penerapan Prinsip-prinsip syariah?

Tujuan penelitian ini adalah mendapatkan informasi tentang impementasi prinsip-prinsip syariah yang diterapkan di MBS Madiun. Hasil penelitian berupa pernyataan dari narasumber saat wawancara. Pernyataan ini merupakan bukti lapangan dari narasumber terkait dengan tema penelitian. Dengan hasil sebagai berikut

a. Bagaimana penerapan prinsip-prinsip syariah di Toko MBS Madiun?

P1 menjawab :

“penerapan prinsip-prinsip syariah yang diterapkan di toko kami seperti prinsip keadilan, prinsip al-ihsan atau kebaikan, prinsip al-mas'uliyah, dan prinsip kejujuran.

b. Apa alasan penerapan Prinsip-prinsip Syariah?

P1 menjawab :

“ alasan dari penerapan prinsip-prinsip syariah dari toko kami adalah untuk mengikuti ajaran Rasulullah dalam melakukan aktivitas ekonomi yang mana beliau selalu memperhatikan kaidah-kaidah Islam dalam segala aktivitas ekonomi yang beliau lakukan. Selain itu dengan menerapkan prinsip-prinsip syariah maka selain mendapatkan keuntungan duniawi juga mendapat keuntungan akhirat."

\section{HASIL DAN PEMBAHASAN}

Dalam sebuah bisnis berbasis syariah, setiap kegiatan ekonominya harus memperhatikan dan mempertimbangkan nilai-nilai kaidah Islam sesuai tuntunan Nabi Muhammad SAW yang terdapat pada Al-Qur'an dan Hadist. Di mana bisnis syariah tidak hanya beroientasi pada kehidupan duniawi saja melainkan juga kehidupan akhirat. MBS Madiun merupakan bisnis ritel syariah berupa minimarket di kota Madiun yang berpedoman pada prinsip-prinsip syariah pada operasionalnya. Prinsip-prinsip syariah 
yang diterapkan di MBS Madiun adalah prinsip keadilan, prinsip al-ihsan, prinsip almas'uliyah, prinsip al-kifayah, prinsip kejujuran dan kebenaran.

Untuk menjaga prinsip-prinsip syariah dan memelihara nilai-nilai Islam, hasil analisa penerapan prinsip-prinsip syariah di toko MDS Madiun pada beberapa aspek diantaranya aspek produk, pelayanan, pemasaran, dan penyaluran keuntungan kepada yang lebih membutuhkan.

\section{Aspek Produk}

Menurut Kotler dan Amstrong (1996:274) produk adalah segala sesuatu yang ditawarkan ke pasar untuk mendapatkan perhatian, dibeli, dipergunakan dan yang dapat memuaskan keinginan atau kebutuhan konsumen. Pada aspek ini produk yang diperjualbelikan di MBS Madiun adalah produk yang benar-benar sudah terjamin hal tersebut dapat dibuktikan dengan label halal pada setiap produk yang dijual. Selain itu MBS Madiun tidak menjual produk-produk yang tidak boleh diperjualbelikan seperti minuman keras, alat kontrasepsi dan barang lainnya. Dengan memperhatikan produk yang diperjual belikan menjadikan MBS Madiun telah menerapkan prinsip syariah al-mas'uliyah yang artinya bertanggungjawab atas barang yang diperjualbelikan dan sesuai dengan nilai-nilai Islam yang ada dalam Al-Qur'an maupun Hadist, yaitu dengan memperjualbelikan produk diperbolehkan dan terjamin halal.

\section{Aspek Pelayanan}

Menurut Kotler (2008:120) pelayanan adalah kegiatan atau tindakan yang dapat ditawarkan oleh suatu pihak kepada pihak lain, yang pada dasarnya tidak berwujud dan tidak mengakibatkan perpindahan kepemilikan (Kotler,2008:120). Pada aspek ini prinsip-prinsip syariah yang diterapakan minimarket MBS Madiun adalah sebagai berikut :

a. karyawan diharuskan memberikan pelayanan semaksimal mungkin bagi para konsumen dengan menerapkan prinsip 3S (senyum, salam, sapa) bagi setiap konsumen yang datang untuk berbelanja di toko MBS Madiun. hal tersebut membuat konsumen akan merasa lebih dihargai dan memberikan kesan yang baik di benak konsumen.

b. Dalam menanggapi komplain, karyawan harus bersikap lemah lembut dan sabar menghadapi konsumen yang komplain. Yaitu dengan mendengarkan komplain dari konsumen kemudian memberikan jawaban atas komplain tersebut dengan 
menggunakan bahasa yang sopan, mudah dipahami dan tidak menyinggung perasaan konsumen.

Dalam aspek pelayanan, prinsip syariah yang diterapkan MBS Madiun adalah prinsip al-ihsan (berbuat kebaikan) dan prinsip al-mas'uliyah (bertanggung jawab). Minimarket berbuat kebaikan dengan memberikan pelayanan yang baik kepada konsumen (service excellent) kemudian bertanggung jawab atas komplain yang diadukan oleh konsumen. Sehingga para konsumen akan memilih untuk berbelanja di MBS Madiun karena merasa lebih dilayani dan dihargai.

\section{Aspek Pemasaran}

Menurut Stanton (2013:1293) pemasaran adalah suatu sistem dari kegiatan ekonomi yang bertujuan untuk merencanakan, menentukan harga, mempromosikan dan mendistribusikan produk yang dapat memenuhi keinginan konsumen untuk mencapai tujuan dari perusahaan. Pada aspek ini prinsip-prinsip pemasaran yang diterapkan MBS Madiun adalah sebagia berikut :

a. Promosi dilakukan dengan jujur, yaitu dalam promosi tidak memberikan janjijanji yang kemudian tidak ditepati dan juga menggunakan media yang diperbolehkan seperti banner dan pamflet. Promosi yang dilakukan bertujuan untuk memperkenalkan produk kepada konsumen, kemudian apabila konsumen merasa butuh dengan produk tersebut maka akan mengunjungi MBS Madiun.

b. Tidak adanya harga yang dimanipulasi, yaitu harga yang diterapkan oleh MBS Madiun adalah harga yang telah diberikan oleh supplier atau harga jual yang direkomendasikan oleh supplier dan tidak menentukan harga sendiri. Harga itu sendiri dapat dilihat pada label harga di setiap produk, sehingga konsumen bisa mengetahui harga setiap produk tanpa harus bertanya kepada karyawan atau kasir.

Dalam aspek pemasaran, prinsip-prinsip syariah yang diterapkan adalah prinsip kebenaran dan kejujuran. Karena promosi dan penentuan harga yang dilakukan MBS Madiun sesuai dengan kebenaran tidak ada manipulasi dan tidak melakukan praktik kecurangan.

\section{Penyaluran keuntungan kepada yang membutuhkan.}

Selain bertujuan untuk mencari keuntungan duniawi MBS Madiun juga mencari keuntungan akhirat dengan cara melakukan menyisihkan keuntungan 
kemudian disalurkan melalui zakat dan sedekah. Zakat yang dilalakukan oleh MBS Madiun adalah zakat perdagangan yaitu 2,5\% dari keuntungan yang diperoleh setiap tahun apabila telah mencapai nisab. Selain itu juga menyisihkan sedikit keuntungan setiap bulan yang digunakan untuk sedekah kepada kaum yang membutuhkan.

Dalam aspek penyaluran keuntungan MBS Madiun menerapkan prinsip syariah al-kifayah (tolong-menolong), karena setiap tahun selalu menunaikan zakat perdagangan sebesar 2,5\% dari keuntungan yang diperoleh oleh toko tersebut. selain itu juga melakukan sedekah yang dilaksankan setiap bulan.

\section{KESIMPULAN}

Berdasarkan penelitian yang telah dilakukan oleh peneliti, maka peneliti mengambil kesimpulan bahwa penerapan prinsip-prinsip syariah pada bisnis ritel MBS Madiun dalam aktivitasnya dapat dilihat dari beberapa aspek yaitu, pada aspek produk yaitu al-masuliyah (bertanggungjawab) atas produk yang dijual dengan menjual produk yang benar-benar halal dibuktikan dengan label halal pada setiap produk yang dijual. Pada aspek pelayanan, menerapkan prinsip al-ihsan (kebaikan) yaitu dengan memberikan service excellent kepada para konsumen dengan menerapkan 3S ( senyum, salam, sapa) sehingga para konsumen merasa lebih dihargai dan prinsip al-masuliyah (bertanggungjawab), yaitu bertanggungjawab atas produk yang diperjualbelikan dan bertanggungjawab atas kekeliruan dan ketika mendapat komplain dari konsumen.

Pada aspek pemasaran, menerapkan prinsip al-sidq (kejujuran) dan kebenaran yang dalam praktiknya hanya menggunakan media promosi yang diperbolehkan dengan tujuan untuk mengenalkan produk tersebut ke konsumen dan juga memberikan harga yang sesuai dengan patokan supplier yang artinya tidak membuat harga sendiri untuk menambah keuntungan pribadi selain itu juga memberikan label harga pada produk sehingga konsumen bisa mengetahui harga setiap produk yang dijual. Pada aspek penyaluran keuntungan kepada yang lain, menerapkan prinsip al-kifayah (tolongmenolong) yang artinya setiap mendapatkan keuntungan selalu menyisihkan kepada yang membutuhkan berupa zakat perdagangan yaitu 2,5\% dari total pendapatan dalam setahun apabila telah memenuhi nisab dan sedekah yang dilakukan setiap bulan. Pada empat aspek tersebut tidak mengandung hal-hal yang dilarang dalam kaidah Islam yang berpedoman pada Al-Qur'an dan Hadist. Jadi secara garis besar bisnis ritel MBS Madiun dalam kegiatan ekonominya telah menerapkan prinsip-prinsip syariah. 


\section{REFERENSI}

Andriani, R. (2019). Analisis Penerapan Prinsip-prinsip Syariah pada Bisnis Ritel Syariah di Minimarket Sakinah 212 Mart Wonorejo Tandes Surabaya. Universitas Islam Negeri Sunan Ampel Surabaya, Surabaya.

Kotler, P. (2016). Kewirausahaan: Teori, Kasus dan Solusi. Bandung: Alfabeta.

Manan, A. (2012). Hukum Ekonomi Syariah Dalam Perpektif Kewenangan Peradilan Agama. Jakarta: Kencana Prenada Media Group.

Mardani. (2015). Hukum Sistem Ekonomi Islam. Jakarta: PT Rajagrafindo Persada.

Mursal. (2015). IMPLEMENTASI PRINSIP-PRINSIP EKONOMI SYARIAH:

Alternatif Mewujudkan Kesejahteraan Berkeadilan). Jurnal Perspektif Ekonomi Darussalam, 1(1), 75-84.

Pasaribu, L. M. R. (2019). ANALISIS PRINSIP DAN PENERAPAN ETIKA BISNIS ISLAM TERHADAP KEMAJUAN BISNIS (Studi Pada Swalayan Surya Jalan Ryacudu Jalur Dua Korpri). UNIVERSITAS AGAMA ISLAM NEGERI RADEN INTAN, Lampung.

Soliha, E. (2008). Analisis Industri Ritel di Indonesia. Jurnal Bisnis dan Ekonomi (JBE), 15(2), 128-142.

Sugiono. (2014). Metode Penelitian Kuantitatif Kualitatif dan $R \&$ D. Bandung: Alfabeta. 